\title{
Flower Symbolism in Chanoyu Spirit
}

\author{
Cicilia Tantri Suryawati \\ Faculty of Letters \\ Dr. Soetomo University \\ Surabaya, Indonesia \\ tantrisuryawati@yahoo.com
}

\author{
Endang Poerbowati \\ Faculty of Letters \\ University of Tujuh Belas Agustus 1945 \\ Surabaya, Indonesia \\ esapajp@yahoo.co.jp
}

\begin{abstract}
Flower is an object favored by most people since the ancient times till now. Flowers as symbol of beauty, love, happiness, and even sadness do not only exist in human everyday life, but also in religious ceremonies, festivals, even the poets also use the word flower as a symbol. Likewise, Chanoyu, which in the Indonesian language is known as tea ceremony, always use flowers in every step of its ritual. The flower as a literal meaning is poured in the form of a wreath as a marker of unity with nature and as a marker of the season, also the flower as a symbol is poured on a Zen proverb written on Kakejiku and hung on the tea room as a symbol of Chanoyu spirit. Chanoyu a tea-drinking tradition in Japan influenced by Zen Buddhism, was introduced to all societies in Japan by Sen no Rikyu in the 16th century. The influence of Zen in Chanoyu is not only on its unity with nature but also carried out with quiet stages as part of meditation to gain peace of mind. These two aspects affect the spirit of Chanoyu, namely, harmony, mutual respect, having a sincere heart, and always maintaining mental calmness that become the basic principle until now. Based on this matter, this paper discussed the symbol of flower that expressed through Zen proverb, taken from the book entitled Ippuku Haiken Zen no Kotoba Ocha no Kokoro by Chisaka Suugaku. This research was conducted to study the metaphorical meaning of the flower stated in the stated proverb that becomes the spirit of Chanoyu.
\end{abstract}

Keywords_flower symbolism; Zen proverb; spirit of Chanoyu.

\section{INTRODUCTION}

Chanoyu, in the Indonesian language commonly called 'Upacara Minum Teh' which is a direct translation of the English term Tea Ceremony, is a traditional Japanese art that is heavy with beauty. Chanoyu consists of the kanji letters "茶 の 湯" "tea" and "hot water", the literal meaning is to brew tea with hot water, introduced in the 9th century by Japanese monk who returned from China, and developed as a tradition of tea ceremony influenced by Zen Buddhism. It is this Zen influence that makes each of Chanoyu's stages quietly performed as part of meditation to gain a balance of soul and self tranquility.

An architectural space designed to be used for Chanoyu is called Chashitsu, where an ornament called kakejiku and flower decoration are hung inside. Kakejuku does not only consist of paintings but also poems that reflect the spirit of Chanoyu. For example, one of the Chanoyu spirits written in a kakejiku is "ichigo ichie" which can simply be interpreted as "there is only one chance in life so do it wholeheartedly."
This paper will discuss the flower symbols reflected in the Zen proverb on a book entitled Ippuku Haiken Zen no Kotoba, Ocha no Kokoro written by Chisaka Shuugaku. This book is the 8th edition published by Tankosha Publisher in Kyoto in 2004. The book Ippuku Haiken Zen no Kotoba Ocha no Kokoro, as it is written in the title, this book contains 96 Zen proverbs related to Chanoyu. As an example of the Zen adage first written in this book is 「ー 三三,,」 "ichi-ni-san. . .". This proverb is written in a flower vase found in Hounsai Iemoto's Chashitsu, where the person who enters the room will see the word. Chisaka (Heisei 2: 14-16) stated that the kanji "ichi ni san. .." which is written in the vase reflects the meaning that the number one in both Zen and Chanoyu thought means " rule "or" way ", truth and immortality. While ". . . " the numeral following the number 1,2,3 reflect the meaning of something eternal, unlimited. In Chanoyu practice everything starts with steps 1-2-3 and will end in step 3-2-1. In monastic Chanoyu it is said that every single step that we go through is enrichment for ourselves ".

In this paper the authors choose Zen adage that contains the word flower. Flowers and Chanoyu are inseparable entities. As mentioned in the previous paragraphs, the decorations in Chashitsu are kakejiku and ikebana. In addition, flowers also exist in our daily lives either in daily activities, prayers, or festivals. Poems also often use the flower as a symbol of something the poet hopes for, whether as a symbol of happiness, love, or sadness. Considering how significant the meaning of flower for our lives is then in this paper the authors will study the symbol of flowers commonly used on kakejiku in chashitsu.

\section{DISCUSSION}

\section{A. Previous Study}

This paper is the third paper written by the researcher to discuss a book entitled Ippuku Haiken Zen no Kotoba Ocha no Kokoro by Chisaka Shuugaku.The first paper was presented on the Japanese Language Education International Research Conference on September 10, 2016 in Bali with the title "The Esthetic Approach on Japanese Poems". The paper discussed the aesthetics of Wabi Sabi on five Zen proverbs, namely, 1. 澗水 湛 如 藍 (kansui tataete aino gotoshi), 2. 行雲流水 (kouen ryuusui), 3. 琴聲 流水 古松 (kinsei ryuusui koshou), 4. 
一 花開 天下 春 (ikka hiraite tenkawa haru), and 5. 花 無心 (hana mushin).

The second paper entitled "The Reflection of the Chanoyu Soul in the Zen Proverb found in kakejiku" and it has been sent to Ayumi Journal of the Japanese Letters Study Program Faculty of Letters - Dr. Soetomo University in January 2018. The paper used Wa-Kei-Sei-Jaku thinking which the soul of Chanoyu to analyze Zen proverbs is. The data used were proverbs containing pine elements in it. There were five proverbs used as research data: (1) 厳 谷 栽 松 (Gankokusaishou) which means "Understanding of Life through Pine Planting", (2) 松 無 古今 色 (Matsu ni Kokon No Iro Nashi) which means The color of the pine is unchanging and everlasting, (3) 松樹千年 翠 (Shouju Sennenno Midori) meaning "pine tree with eternal green", (4) 閑坐 聴 松風 (Kanzashite Shoufuwo Kiku) meaning "Sitting comfortably listening to the rustle of the sound of the wind on the tree Pinus ", and (5) 松老雲自閑 (Matsu Oite Kumo Onozukara Shizuka) meaning "Old Pine and Cloud as forms of tranquility".

In writing this paper, the researchers use Zen proverbs containing the name of flower. In accordance with the title, then this research will discuss the meaning of flowers in the spirit of Chanoyu. There are three flowers that are used in this book: Chrysanthemum flower $\ulcorner\square\lrcorner$ (kiku), plum flower $\ulcorner\square\lrcorner$ (ume), and pine flower「口u」(matsubana) used in the Zen

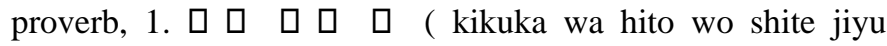

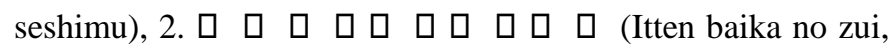
sanzen sekai kanbashi) . 4. 5. 6. 7. 8 .

\section{B. Analysis}

1) 菊花令人寿 (kikuka wa hito o shite jiyu seshimu)

This Zen proverb is used as a display hung in the teaceremony room (Chagake) in September and October when Japan starts the autumn. Autumn is the season to harvest the crop. Besides, on the ninth day of the ninth month (September) the Japanese people hold Choyo festival. The Choyo Festival or the Chrysanthemum festival is a celebration to invoke a bliss and long life.

When it is examined literally the meaning of the kanji then 菊 化 (kikuka meaning Kiku flower / chrysanthemum / seashore flower) 令人 寿 (rei jin ju means the decision of life). Literally, the proverb means Chrysanthemum Flowers that became the decision of life. For the Japanese community the flower of Chrysanthemum is a symbol of loyalty, optimism, happiness, and long life prayer. Therefore the purpose of displaying this proverb is when someone gets fortune or when someone expects something good.

The meaning of luck, something good, or it can be said a happiness for humans will be different from one another. Happiness in the spirit of Chanoyu, as Sen Soushitsu [1, p. 20] said，「自分自身で自分のカで、自分の気持ちを清めよう という心がー番大切なのである。このようなゆとりがあ なたにあるとすれば、それは非常に幸せであるといえる
だろう。」(Jibun jishin de jibun no chikara de, jibun no kimochi wo kiyomeyou to iu kokoro ga ichiban taisetsuna no de aru Kono youna yutori ga anata ni aru to sureba, afternoon wa hijou ni shiawase de aru to ieru darou) "the most important thing is the heart that seeks to purify oneself with trust, strength, and self-will. It is not something that is really happy, isn't?" Therefore, the meaning of the Chrysanthemum flower in this proverb is purity.

\section{2) 一點梅花楽 三千世界香 "Itten baika no zui, sanzen} sekai kanbashi"

The above proverb uses Plum flower as symbol. The flower blooms at the end of winter when the snow is still falling. The blooming plums withstand wind and snow that is extremely cold is served as an example of a lesson of difficult life.

A master Zen, Houunsai Iemoto said "Life is like a prickly path that is not easy to pass. And there is only one word that "holding it". When you pass through it calmly then you will find the hidden strength within. That's why there is happiness right now. Hope you understand it.

From that statement and when he saw the blossoming Plum flower, Shuugaku said "when I saw the flower of Prem, I thought it would not be possible to get the the real tea taste it is not discipline in the way of tea. Nowadays discipline has been forgotten, people are only pursuing knowledge. Therefore, the experience of wisdom will not be obtained"

一點梅花の葆、三千世界に香ばし "Ittebaika no sui, sanzen sekai ni kanbashi" "Ittebaika no sui, sanzen sekai ni kanbashi" which in literal meaning means "a point of flower pollen of Plum flower is flown into the air will devour three worlds". The stament of Plum flower appears in a very violent natural atmosphere (snow and wind) but when it blooms it will give birth to a fascinating beauty. If it is associated with Chanoyu, it will mean "through Sadou (the way of tea) with steadfastness, training oneself in a strong and long discipline will be a virtuous person so as to spread goodness throughout the world. Further Shuugaku stated "I want to interpret it that in holding (patience), it is necessary to maintain a noble character within."

In the Spirit of Chanoyu, steadfastness, self-discipline, and patience are reflected in the "jaku" spirit of tranquility. Sen Soushitsu [1, p. 21] wrote 「督はどういう意味であるかと 言うと、これはどんな時にでも動じない心であるといえ る」”Jaku wa dou iu imi ka to iu to, kore wa donna toki demo doujina kokoro de aru to ieru" (what is meant by " jaku " is to have an unswerving heart at any moment).

Sen Soushitsu gives an example when in the class suddenly the teacher asks us and we cannot answer at all. In such circumstances it will usually blow "if only I prepared it ...” it will not happen if we are always disciplined in everything because no one can predict his future. Having strong discipline, cultivating great patience, and doing careful preparation for everything will keep us from shame and failure.

Plum Flowers preparing themselves in coping with harshness of nature so that it can be beautiful flower whose 
fragrant perfumes universe is the description of human beings who discipline themselves, preparing everything composedly, resulting in a virtue that can be a source of goodness and happiness for others.

\section{3) 松花伴鶴飛(Shouka wa tsuru wo tomonatte tobu)}

Pine Tree is a strong tree facing any weather. In the summer the leaves are green, in the winter when other trees shed their leaves, the pine tree stands still with its green leaves amid the white snow expanse. Pine can live for thousands of years. For the Japanese people since ancient times, the pine tree is believed to be a tree of luck or happiness. The pine symbolizes happiness and longevity. In addition to pine trees, Stork is also a symbol of longevity for Japanese society.

The above Zen proverb can be interpreted as "Flower of Pines flown by the wind along with the crane". The pollen of pine flower flown by the wind along with the Stork symbolizes the fate of a couple. This proverb is often used as welcoming words hung in a small space at the wedding ceremony.

The harmony described in this maxim symbolizes the word "WA" in the spirit of Chanoyu. Sen Soushitsu briefly explains the meaning of "WA" in the spirit of Chanoyu as follows "WA" is the amity between one another in harmonious situation (1995: 20). Harmony in chanoyu is not only on the relationship among humans, but also the harmony between humans and nature. We are living in harmony with the natural surroundings, treating the tea equipment with great care in the hope that nature will do for us as we do for it. In daily life "WA" can also be interpreted as teamwork.

As it is in life, human being cannot do everything himself so does Chanoyu. Chanoyu cannot be done alone; a mutually respectful cooperation taught in the spirit of chanoyu "kei" mutual respect is the expected form of harmony in chanoyu. As it is illustrated by the proverb above that the pollen flown by the wind along with the stork is a natural harmony bringing new life that is pine flower that will become pine trees living hundreds of years illustrates the form of harmony resulting in virtue for a long and peaceful life.

\section{CONCLUSION}

In the book "Ippuku Haiken Zen no Kotoba Ocha no Kokoro" written by Chisaka Shuugaku, there are 96 Zen proverbs. There are only 3 proverbs using the name of flowers, namely, Kiku, Ume, and Matsu hana among those 96 Zen proverbs.

In Chanoyu Spirit, Kiku (Chrysanthemum) is a symbol of "Kei" meaning cleanness or purity. It is a spirit to always serve with everything that is clean, which is not only visible material but the most important matter, is a clean heart when facing others to achieve a harmony (Wa) resulting in life happiness.

Through the hidden power behind the beauty of Plum / Ume Flowers, Chanoyu expresses it with the spirit of "Jaku" that is tranquility. It is a description of human who disciplines himself, prepares everything calmly, resulting in a virtue that can be a source of goodness and happiness for others.

Pine Flower (matsubana) is a description of "Wa" in Chanoyu spirit. "Wa" is the amity between one another. A respectful cooperation that is taught also in the spirit of chanoyu "kei" that is mutual respect is a form of harmony resulting in virtue for a long and peaceful life is what is expected in chanoyu.

The above three flowers symbolize the entire spirit of Chanoyu. They are "wa kei sei jaku" which are bound to each other.

\section{REFERENCES}

[1] S. Sen, Sadou. Kyoto: Sadou Kyoushitsu Sentaa, 1995.

[2] S. Chisaka, Ippuku Haiken Zen no Kotoba, Ocha no Kokoro. Tokyo: Tankosha, 1990.

[3] K. Djojosuroto, Puisi, Pendekatan dan Pembelajaran [Poems, Approach, and Learning]. Bandung : Penerbit Nuansa, 2005.

[4] C. Katsuhiro, Nihon - Sono Sugata to Kokoro. Tokyo: Gakuseisha, 1997.

[5] T. Okakura, The Book of Tea. Tokyo: Kodansha, 1998.

[6] S. Soko, Ocha no Okeiko Nyuumonsho. Tokyo: Shinsei, 2009.

[7] A. Tani, Wakariyasui Chanoyu no Bunka. Kyoto: Tankousha, 2005. 